\title{
Urbanization, unemployment and migration in Africa: Theory and policy
}

Michael P. Todaro

Follow this and additional works at: https://knowledgecommons.popcouncil.org/departments_sbsr-pgy

Part of the Demography, Population, and Ecology Commons, Family, Life Course, and Society Commons, International Public Health Commons, and the Migration Studies Commons How does access to this work benefit you? Let us know!

\section{Recommended Citation}

Todaro, Michael P. 1997. "Urbanization, unemployment and migration in Africa: Theory and policy," Policy Research Division Working Paper no. 104. New York: Population Council. 


\section{Urbanization, Unemployment, and M igration in Africa: Theory and Policy}

Michael P. Todaro 


\title{
Urbanization, Unemployment, and Migration in Africa: Theory and Policy
}

\author{
Michael P. Todaro
}

Michael P. Todaro is Professor of Economics, New York University, and Consulting Senior Associate, Population Council. Paper prepared for Reviewing Social and Economic Progres in Africa. Macmillan, forthcoming. Ed. Dharam Ghai. This paper draws on material that appears in Chapter 8 of the author's book, Economic Development, sixth edition. 1997. New York and London: Longman. 


\section{Abstract}

During the past three decades, the cities of the developing world in general, and of Africa in particular, have witnessed a remarkable and in many ways unprecedented demographic growth spurt. Despite some slowdown in rates of increase in the past few years as a result of falling wages, contracting social services, and changing demographic trends, contemporary urban areas remain the growth poles of economic progress and the lightning rods of political and social unrest. Nowhere is this dilemma more visible nor the resulting problems more intractable than in the crowded cities of sub-Saharan Africa, where projections of urban population growth remain the highest in the world.

This essay focuses on the conceptual, empirical, and policy-relevant linkages among urbanization, rural-urban migration, and economic development. First, recent trends and future scenarios for urban population growth are reviewed, with special emphasis on African urbanization. Then, the growth and significance of the urban informal economy and the role of women in informal economic activities are examined. Rural-urban migration is discussed in both a descriptive and an analytical framework; the economic crisis in Africa and its relationship to urbanization and migration are considered. An analysis of policy options designed to ameliorate the deteriorating economic, social, and environmental dilemmas posed by Africa's rapid urban growth concludes the study.

This material may not be reproduced in any form without written permission from the author. 
One of the most significant of all postwar demographic phenomena and the one that promises to loom even larger in the future is the rapid growth of cities in developing countries. In 1950, some 275 million people were living in third world cities, 38 percent of the 724 million total urban population. According to United Nations estimates, the world's urban population had reached 2.3 billion by 1990 , with 61 percent ( 1.4 billion) living in the cities of developing countries. The UN projects that in 2025, more than 4 billion, or 77 percent of the urban dwellers of the world, will reside in less developed regions. This number will represent an overall increase of 186 percent, or 2.61 billion new urbanites in Africa, Asia, and Latin America since 1990. Depending on the nature of development strategies pursued, the total in 2025 could be substantially higher or lower than the 4 billion estimate. Figure 1 provides a three-stage portrayal of the projected growth of

Figure 1 Urban population estimates and projections, developing regions and China, 1950-2000

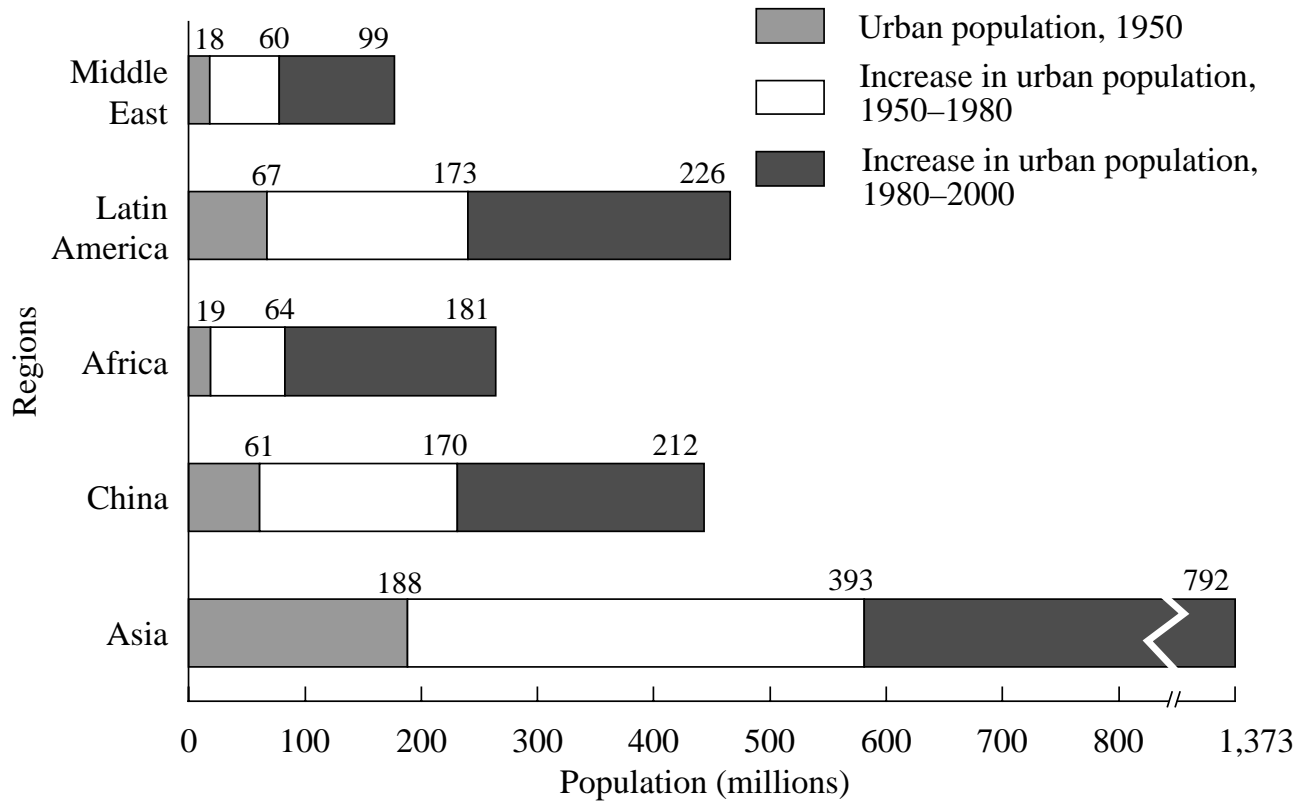


urban populations in four developing regions and China between 1950 and 2000; Table 1 presents a more detailed statistical breakdown with projections to 2025 . $^{1}$

With regard to particular cities, current rates of population growth range from less than 1 percent per annum in two of the world's largest cities, Tokyo and New York, to more than 6 percent per annum in many African cities, including Nairobi, Lagos, and Lusaka. In Asia and Latin America, many cities are growing at rates in excess of 5 percent per annum. Table 2 provides data on the world's 15 largest cities in 1950 and 1995 together with UN projections to 2015. In 1950, only four of the 15 were in the developing world. Their combined population was 19 million. In 1995, 12 out of the 15 largest cities were in the developing world, with a total population of 152

Table 1 Urban population estimates and projections in major world regions, 1950-2025 (millions)

\begin{tabular}{lrrrrrrr}
\hline & \multicolumn{7}{c}{ Population } \\
\cline { 2 - 8 } Region & $\mathbf{1 9 5 0}$ & $\mathbf{1 9 6 0}$ & $\mathbf{1 9 7 0}$ & $\mathbf{1 9 8 0}$ & $\mathbf{1 9 9 0}$ & $\mathbf{2 0 0 0}^{\mathbf{a}}$ & $\mathbf{2 0 2 5}^{\mathbf{a}}$ \\
\hline World & 724 & 1,012 & 1,352 & 1,807 & 2,282 & 3,208 & 5,187 \\
$\begin{array}{l}\text { More-developed } \\
\text { regions }\end{array}$ & 449 & 573 & 698 & 834 & 881 & 965 & 1,177 \\
$\quad \begin{array}{l}\text { Less-developed } \\
\quad \text { regions }\end{array}$ & 275 & 439 & 654 & 972 & 1,401 & 2,101 & 4,011 \\
$\begin{array}{l}\text { Africa } \\
\text { Latin America }\end{array}$ & 32 & 50 & 83 & 133 & 206 & 331 & 857 \\
Asia & 68 & 107 & 162 & 241 & 315 & 413 & 592 \\
\hline
\end{tabular}

Sources: United Nations (1980), Patterns of Urban and Rural Population Growth. New York: United Nations. Pii Elina Berghäll (1995), Habitat II and the Urban Economy: A Review of Recent Developments and Literature. Helsinki: United Nations University World Institute for Development Economics Research. Tables 2 and 4.

a Estimate. 
Table 2 The world's fifteen largest cities, 1950, 1995, and 2015 (millions)

\begin{tabular}{lclclc}
\hline City & $\begin{array}{c}\text { 1950 } \\
\text { Population } \\
\text { (millions) }\end{array}$ & City & $\begin{array}{c}\text { 1995 } \\
\text { Population } \\
\text { (millions) }\end{array}$ & City & $\begin{array}{c}\text { 2015 } \\
\text { Population } \\
\text { (millions) }\end{array}$ \\
\hline 1. New York & 12.3 & Tokyo & 26.8 & Tokyo & 28.7 \\
2. London & 8.7 & São Paulo & 16.4 & Bombay & 27.4 \\
3. Tokyo & 6.9 & New York & 16.3 & Lagos & 24.4 \\
4. Paris & 5.4 & Mexico City & 15.6 & Shanghai & 23.4 \\
5. Moscow & 5.4 & Bombay & 15.1 & Jakarta & 21.2 \\
6. Shanghai & 5.3 & Shanghai & 15.1 & São Paulo & 20.8 \\
7. Essen & 5.3 & Los Angeles & 12.4 & Karachi & 20.6 \\
8. Buenos Aires & 5.0 & Beijing & 12.4 & Beijing & 19.4 \\
9. Chicago & 4.9 & Calcutta & 11.7 & Dhaka & 19.0 \\
10. Calcutta & 4.4 & Seoul & 11.6 & Mexico City & 18.8 \\
11. Osaka & 4.1 & Jakarta & 11.5 & New York & 17.6 \\
12. Los Angeles & 4.0 & Buenos Aires & 11.0 & Calcutta & 17.6 \\
13. Beijing & 3.9 & Tianjin & 10.7 & Delhi & 17.6 \\
14. Milan & 3.6 & Osaka & 10.6 & Tianjin & 17.0 \\
15. Berlin & 3.3 & Lagos & 10.3 & Manila & 14.7 \\
\hline
\end{tabular}

Sources: United Nations (1995), World Urbanization Prospects: The 1994 Revision. New York: United Nations. Table 1. The World Resources Institute (1996), World Resources 199697: The Urban Environment. New York: Oxford University Press. Table 1.1.

million. By 2015, cities in less-developed countries (LDCs) are anticipated to comprise 13 of the 15 largest, with a combined population in excess of 261 million. Note in particular how Lagos, Nigeria, which does not even appear on the list until occupying the fifteenth position in 1995, jumps to the number three spot in 2015, as its population grows by more than 135 percent during the 20-year period. In fact, if we focus solely on African urban areas (as in Table 3), we find that the phenomenal growth of Lagos is the rule 
Table 3 African and regional urban growth rates, 1990-95, and percent urban, 1975, 1995, and 2025

\begin{tabular}{|c|c|c|c|c|}
\hline \multirow[b]{2}{*}{ Country/region } & \multirow{2}{*}{$\frac{\text { Urban growth rate }}{1990-95 \text { (percent) }}$} & \multicolumn{3}{|c|}{ Percent urban } \\
\hline & & 1975 & 1995 & 2025 \\
\hline \multicolumn{5}{|l|}{ Country } \\
\hline Botswana & 7.0 & 12 & 28 & 56 \\
\hline Burkina Faso & 11.2 & 6 & 27 & 66 \\
\hline Burundi & 6.6 & 3 & 8 & 21 \\
\hline Ghana & 4.3 & 30 & 36 & 58 \\
\hline Kenya & 6.8 & 13 & 28 & 51 \\
\hline Lesotho & 6.2 & 11 & 23 & 47 \\
\hline Malawi & 6.2 & 8 & 14 & 32 \\
\hline Mozambique & 7.4 & 9 & 34 & 61 \\
\hline Nigeria & 5.2 & 23 & 39 & 62 \\
\hline Tanzania & 6.1 & 10 & 24 & 48 \\
\hline Uganda & 5.8 & 8 & 13 & 29 \\
\hline Zimbabwe & 5.0 & 20 & 32 & 55 \\
\hline \multicolumn{5}{|l|}{ Region } \\
\hline Africa & 4.4 & 25 & 34 & 55 \\
\hline South America & 2.5 & 64 & 78 & 88 \\
\hline Asia & 3.3 & 25 & 35 & 55 \\
\hline Europe & 0.6 & 67 & 74 & 83 \\
\hline
\end{tabular}

Source: The World Resources Institute (1996), World Resources 1996-97. New York: Oxford University Press. Data table A.1.

rather than the exception. Although their absolute numbers are lower than many Asian and Latin American cities, African cities have uniformly higher growth rates and more rapidly expanding numbers.

A central question related to the unprecedented size of these urban agglomerations is how African cities will cope-economically, environmen- 
tally, and politically — with such acute concentrations of people. Whereas cities offer the cost-reducing advantages of agglomeration economies and economies of scale and proximity as well as numerous economic and social externalities (for example, skilled workers, cheap transport, social and cultural amenities), the social costs of a progressive overloading of housing and social services, not to mention increased crime, pollution, and congestion, tend gradually to outweigh these historical urban advantages. Former World Bank president Robert McNamara expressed his skepticism that huge urban agglomerations could be made to work at all:

These sizes are such that any economies of location are dwarfed by costs of congestion. The rapid population growth that has produced them will have far outpaced the growth of human and physical infrastructure needed for even moderately efficient economic life and orderly political and social relationships, let alone amenity for their residents. ${ }^{2}$

Along with the rapid spread of urbanization and the urban bias in development strategies has come the prolific growth of huge slums and shantytowns. From the favelas of Rio de Janeiro and the pueblos jovenes of Lima to the bustees of Calcutta and the bidonvilles of Dakar, such makeshift communities have been doubling in size every five to ten years. Today slum settlements represent more than one-third of the urban population in all developing countries; in many cases they account for 60 percent or more of the urban total (as shown in Table 4). During the late 1980s, fully 72 of every 100 new households established in urban areas of developing countries were located in shanties and slums. In Africa, the number was 92 out of every 100. 
Table 4 Residents of slums and squatter settlements as a percentage of urban population, by region and city

Region/city

Slum dwellers as percentage

Latin America

Bogotá, Colombia $\quad 60$

Mexico City, Mexico $\quad 46$

Caracas, Venezuela 42

Middle East and Africa

Addis Ababa, Ethiopia $\quad 79$

Casablanca, Morocco $\quad 70$

Ankara, Turkey $\quad 60$

Cairo, Egypt $\quad 60$

Kinshasa, Zaire $\quad 60$

\section{Asia}

Calcutta, India

Manila, Philippines

Seoul, South Korea

Jakarta, Indonesia

Source: Population Crisis Committee (1983), World Population Growth and Global Security, Report No. 13.Washington, DC: Population Crisis Committee. Page 2.

Most of the settlements lack clean water, sewage systems, and electricity. For example, metropolitan Cairo is attempting to cope with a population of 10 million people with a water and sanitation system built to serve 2 million. Thirty percent of the population of Abidjan, Côte d'Ivoire lives without piped water and 70 percent without sewers. Similar conditions can be found in Nairobi, Lusaka, Kinshasa, Dakar, and Lagos where economic decline over the past decade has led not only to falling incomes and rising unemployment but also to a breakdown in urban services and rising social tensions. 
Although population growth and accelerated rural-to-urban migration are chiefly responsible for the expansion of urban shantytowns, part of the blame rests with LDC governments. Their misguided policies regarding urban planning and their outmoded building codes often mean that 80 to 90 percent of new urban housing is "illegal." For example, colonial-era building codes in Nairobi make building a house according to official standards for less than US $\$ 3,500$ impossible. The law also requires that every dwelling be accessible by car. As a result, two-thirds of Nairobi's land is occupied by 10 percent of the population, while 100,000 slum dwellings cannot be improved legally. Similarly, in Manila, 88 percent of the population is too poor to be able to buy or rent an officially "legal" house. ${ }^{3}$

In developing countries, the extent of government concern and even alarm at the trends in urban population growth was vividly revealed in a 1988 UN report on population policies in the world. ${ }^{4}$ It showed that out of a total of 158 countries, 73, all but five of which were developing nations, considered the geographic distribution of their population "highly unacceptable." Another 66 countries, 42 of them developing, considered their urban population size "unacceptable to a degree." Only six developing countries considered their distribution acceptable. Almost all countries dissatisfied with the size and growth of their urban population believed that internal rural-urban migration was the dominant factor contributing to city growth. Statistics show that rural migrants constitute roughly 35 to 65 percent of recorded urban population growth (see Table 5). Accordingly, 90 out of 116 developing countries responding to the UN survey indicated that they had initiated policies to slow or reverse their accelerating trends in rural-urban migration.

Given this widespread dissatisfaction with rapid urban growth in Africa and other developing regions, the critical issue that must be addressed is 
Table 5 Rural-urban migration as a percentage of urban population growth, selected developing countries

\begin{tabular}{lcc}
\hline Country & $\begin{array}{c}\text { Annual urban } \\
\text { growth }\end{array}$ & $\begin{array}{c}\text { Share of growth due } \\
\text { to migration }\end{array}$ \\
\hline Argentina & 2.0 & 35 \\
Brazil & 4.5 & 36 \\
Colombia & 4.9 & 43 \\
India & 3.8 & 45 \\
Indonesia & 4.7 & 49 \\
Nigeria & 7.0 & 64 \\
Philippines & 4.8 & 42 \\
Sri Lanka & 4.3 & 61 \\
Tanzania & 7.5 & 64 \\
Thailand & 5.3 & 45
\end{tabular}

Source: K. Newland (1980), City Limits: Emerging Constraints on Urban Growth, Worldwatch Paper No. 38. Washington, DC: Worldwatch. Page 10.

the extent to which national governments can formulate development policies that can have a definite impact on trends in urban growth. Clearly, the unquestioning pursuit of the orthodox development strategies of the past few decades, with their emphasis on industrial modernization, technological sophistication, and metropolitan growth, created a substantial geographic imbalance in economic and noneconomic opportunities and contributed significantly to the steadily accelerating influx of rural migrants into urban areas. (Some noneconomic components of this urban-rural imbalance are vividly portrayed for Kenya in 1993 in Table 6.) Is it possible or even desirable to attempt to reverse these trends now by pursuing a different set of population and development policies? With birthrates beginning to decline in some African countries, the problem of rapid urban growth and accelerated ruralurban migration undoubtedly will be one of the most important development 
Table 6 Urban versus rural demographic and health characteristics, Kenya, 1993

Characteristic

Urban residents

Rural residents

Household population with no education

Female (6 years and older)

(percent)

(percent)

Male (6 years and older)

13.5

29.1

7.0

18.2

Household possessions and amenities

Radio

67.7

48.1

Television

22.0

2.4

Electricity

42.5

3.4

Drinking water piped to residence

55.8

10.7

Flush toilet

44.9

1.6

\section{Health of children}

Mortality rate of children under age $5^{\text {a }}$

75.4

95.6

Infant mortality rate ${ }^{\mathrm{a}}$

45.5

64.9

Children 12 to 23 months with all vaccinations

80.9

78.3

Underweight $^{\mathrm{b}}$

12.8

23.5

\section{Maternal health}

Women receiving tetanus toxoid during pregnancy

Women receiving prenatal care from a health provider $^{\mathrm{C}}$

Women receiving delivery care from a health provider $^{\mathrm{C}}$

Total fertility rate ${ }^{\mathrm{d}}$

${ }^{a}$ Deaths per 1,000 live births. Mortality rates by characteristics such as place of residence are based on the last ten years prior to the survey in order to ensure sufficient sample size. Mortality rates are based on a minimum of 500 live births.

${ }^{\mathrm{b}}$ Underweight is defined as the percentage of children whose height-for-age, weight-forage, weight-for-height z-score is below -2 standard deviations from the median of the International Reference Population (World Health Organization/Centers for Disease Control/ National Center for Health Statistics).

${ }^{c}$ Doctor, nurse, or trained midwife.

${ }^{\mathrm{d}}$ Births per woman.

Source: Institute for Resource Development, Demographic and Health Survey Archive, Columbia, MD. 
and demographic issues of the early twenty-first century. Within urban areas, the growth and development of the informal sector as well as its role and limitations for labor absorption and economic progress will assume increasing importance. A brief look at this unique component of African and other developing cities is, therefore, in order.

\section{THE URBAN INFORMAL SECTOR}

A major focus of development theory has been on the dualistic nature of developing countries' national economies - the existence of a modern, urban, capitalist sector geared toward capital-intensive, large-scale production and a traditional, rural, subsistence sector geared toward labor-intensive, small-scale production. In recent years, this dualistic analysis has also been applied specifically to the urban economy, which has been decomposed into a formal and an informal sector.

The existence of an unorganized, unregulated, and mostly legal but unregistered informal sector was recognized in the early 1970s, following observations in several African countries that massive additions to the urban labor force failed to show up in formal modern-sector unemployment statistics. The bulk of new entrants into the urban labor force seemed to create their own employment or to work for small-scale, family-owned enterprises. The self-employed were engaged in a remarkable array of activities, ranging from hawking, street vending, letter writing, knife sharpening, and junk collecting to selling fireworks, engaging in prostitution, drug peddling, and snake charming. Others found jobs as mechanics, carpenters, small-scale artisans, barbers, apprentices, and personal servants. Still others were highly successful small-scale entrepreneurs with several employees (mostly relatives) and 
high incomes. Some eventually graduated to the formal sector, where they become legally registered, licensed, and subject to government regulations. Studies reveal that the share of the urban labor force engaged in informalsector activities ranges from 20 to 70 percent, the average being around 50 percent (see Table 7). Given the unprecedented rate of growth of the urban population in developing countries that is expected to continue and the increasing failure of the rural and urban formal sectors to absorb additions to the labor force, researchers are devoting more attention to the role of the informal sector in serving as a panacea for the growing unemployment problem.

The informal sector is characterized by a large number of small-scale production and service activities that are individually or family owned and use labor-intensive and simple technology. Such enterprises tend to be operated like monopolistically competitive firms with ease of entry, excess capacity, and competition driving profits (incomes) down to the average supply price of labor of potential new entrants. The usually self-employed workers in this sector have little formal education, are generally unskilled, and lack access to financial capital. As a result, worker productivity and income tend to be lower in the informal sector than in the formal sector. Moreover, workers in the informal sector do not enjoy the measure of protection afforded by the formal modern sector in terms of job security, decent working conditions, and old-age pensions. Most workers entering this sector are recent migrants from rural areas unable to find employment in the formal sector. Their motivation is usually to obtain sufficient income to survive, relying on their own indigenous resources to create work. As many members of the household as possible, including women and children, are involved in income-generating activities, and they often work very long hours. Most inhabit shacks that they have built themselves in slums and squatter settle- 
Table 7 Estimated percentage of the urban labor force in the informal sector in selected developing countries

\begin{tabular}{ll}
\hline Area & Percent \\
\hline
\end{tabular}

Africa

Abidjan, Côte d'Ivoire 31

Lagos, Nigeria $\quad 50$

Kumasi, Ghana $\quad 60-70$

Nairobi, Kenya $\quad 44$

Urban areas, Senegal $\quad 50$

Urban areas, Tunisia 34

\section{Asia}

Calcutta, India

Ahmedabad, India

Jakarta, Indonesia

Colombo, Sri Lanka

Urban areas, western Malaysia $\quad 35$

Singapore $\quad 23$

Urban areas, Thailand 26

Urban areas, Pakistan $\quad 69$

\section{Latin America}

Córdoba, Argentina 38

São Paulo, Brazil 43

Urban areas, Brazil $\quad 30$

Rio de Janeiro, Brazil $\quad 24$

Belo Horizonte, Brazil 31

Urban areas, Chile $\quad 39$

Bogotá, Colombia 43

Santo Domingo, Dominican Republic $\quad 50$

$\begin{array}{ll}\text { Guayaquil, Ecuador } & 48\end{array}$

Quito, Ecuador 48

San Salvador, El Salvador $\quad 41$

$\begin{array}{ll}\text { Federal District and State of Mexico } & 27\end{array}$

Mexico, D.F., Guadalajara, and Monterey $\quad 42$

Asunción, Paraguay $\quad 57$

Urban areas, Peru $\quad 60$

Urban areas, Venezuela $\quad 44$

$\begin{array}{lr}\text { Caracas, Venezuela } & 40\end{array}$

Kingston, Jamaica 33

Source: S.U. Sethuraman (1981), The Urban Informal Sector in Developing Countries. Geneva: International Labour Organization. 
ments generally lacking minimal public services. Others are less fortunate. Many millions are homeless, living on the pavements of Calcutta, Manila, Dakar, Nairobi, Rio de Janeiro, Bogotá, and many other third world cities. They find sporadic, temporary employment in the informal sector as day laborers and hawkers, but their incomes are insufficient to provide even the most rudimentary shelter.

In terms of its relationship to other sectors, the informal sector is linked with the rural sector in that it allows unskilled laborers to escape from rural poverty and underemployment, although it grants them living and working conditions and incomes that are not much better than what they had had before moving. It is closely connected with the formal urban sector: The formal sector depends on the informal sector for cheap inputs and wage goods for its workers, and the informal sector, in turn, depends on the growth of the formal sector for a good portion of its income and clientele. The informal sector also often subsidizes the formal sector by providing raw materials and basic commodities for its workers at artificially low prices maintained through the formal sector's economic power and legitimacy granted by the government.

The important role that the informal sector plays in providing income opportunities for the poor is no longer open to debate. The question remains, however, as to whether the informal sector is merely a holding ground for people awaiting entry into the formal sector and, as such, is a transitional phase that must be made as comfortable as possible until it is absorbed by the formal sector, or whether it is here to stay and should, in fact, be promoted as a major source of employment and income for the urban labor force. ${ }^{5}$

A good argument can be made in support of the latter view. The formal sector in developing countries has a small base in terms of output and em- 
ployment. In order to absorb future additions to the urban labor force, the formal sector must be able to generate employment at the high rate of at least 10 percent per annum, according to estimates made by the International Labour Organization (ILO). This requirement means that output must grow at an even faster rate, because employment in this sector increases less than proportionately in relation to output. This sort of growth seems highly unlikely to occur in view of current trends. Thus the burden on the informal sector to absorb more labor will continue to increase unless other solutions to the urban unemployment problem are provided. Moreover, the informal sector has demonstrated its ability to generate employment and income for the urban labor force. As noted above, it is already absorbing an average of 50 percent of the urban labor force. Some studies have shown the informal sector to be generating almost one-third of urban income.

Eight other arguments can be made in favor of promoting the informal sector. First, scattered evidence indicates that the informal sector generates surplus even under the currently hostile policy environment, which denies it access to the advantages offered to the formal sector, such as the availability of credit, foreign exchange, and tax concessions. Thus the informal sector's surplus could provide an impetus to growth in the urban economy. Second, as a result of its low capital intensity, only a fraction of the capital needed in the formal sector is required to employ a worker in the informal sector, offering considerable savings to developing countries so often plagued with capital shortages. Third, by providing access to training and apprenticeships at substantially lower costs than that provided by formal institutions and the formal sector, the informal sector can play an important role in the formation of human capital. Fourth, the informal sector generates demand for semi- 
skilled and unskilled labor, the supply of which is increasing in both relative and absolute terms and which is unlikely to be absorbed by the formal sector with its growing demands for a skilled labor force. Fifth, the informal sector is more likely to adopt appropriate technologies and make use of local resources, allowing for a more efficient allocation of resources. Sixth, the informal sector plays an important role in recycling waste materials, engaging in the collection of goods ranging from scrap metals to cigarette butts, many of which find their way to the industrial sector or provide basic commodities for the poor. Seventh, promotion of the informal sector would ensure an increased distribution of the benefits of development to the poor, many of whom are concentrated there. Finally, and perhaps most important, the informal sector provides a major source of income and employment for women, many of whom are heads of households and who have been displaced by agricultural mechanization.

Promotion of the informal sector is not, however, without its disadvantages. One major disadvantage lies in the strong relationship between rural-urban migration and labor absorption in the informal sector. Migrants from the rural sector have both a lower unemployment rate and a shorter waiting period before obtaining a job in the informal than in the formal sector. Promoting income and employment opportunities in the informal sector could, therefore, aggravate the urban unemployment problem by attracting more labor than either the informal or the formal sector could absorb. Furthermore, concern exists over the environmental consequences of a highly concentrated informal sector in the urban areas. Many informal-sector activities cause pollution and congestion (for example, pedicabs) or inconvenience to pedestrians (for example, hawkers and vendors). Moreover, in- 
creased densities in slums and low-income neighborhoods, coupled with poor urban services, could cause enormous health and environmental problems for urban areas. Any policy measures designed to promote the informal sector must incorporate means of coping with these various issues.

Limited discussion has appeared in the literature about what sorts of measures might be adopted to promote the informal sector. The ILO has made some general suggestions. At the start, governments will have to dispense with their currently hostile attitudes toward the informal sector and maintain a more positive and sympathetic posture. For example, in Latin America, bureaucratic red tape and an inordinate number of administrative procedures required for registering a new business typically result in delays of up to 240 days in Ecuador, 310 days in Venezuela, and 525 days in Guatemala. Brazil, Mexico, and Chile all require more than 20 applications before a company can be approved for conducting business. These procedures not only cause excessive delays but also can inflate the costs of doing business by as much as 70 percent annually. Many informal-sector businesses simply skirt the law.

Because access to skills plays an important role in determining the structure of the informal sector, governments should facilitate training in the areas that are most beneficial to the urban economy. In this way, the government can play a role in shaping the informal sector so that it contains production and service activities that provide the most value to society. Specifically, such measures might promote legal activities, and discourage illegal ones, by providing proper skills and other incentives. They could also generate taxes that now go unpaid.

The lack of capital is a major constraint on activities in the informal sector. The provision of credit would, therefore, permit these enterprises to 
expand, produce more profit, and generate more income and employment. Access to improved technology would have similar effects. Providing infrastructure and suitable locations for work (for example, designating specific areas for vendors' stalls) could help alleviate some of the environmental consequences of an expanded informal sector. Most important, improved living conditions must be provided, if not directly, then by promoting growth of the sector on the fringes of urban areas or in smaller towns where the population will settle close to its new area of work, away from urban density. Promotion of the informal sector outside the urban areas may also help redirect the flow of rural-urban migration, especially if it is carried out in conjunction with the policies discussed below.

\section{WOMEN IN THE INFORMAL SECTOR}

In some regions of the world, women predominate among rural-urban migrants and may even comprise the majority of the urban population. Although historically, many of these women were simply accompanying their spouses, a growing number of unmarried African women migrate to seek economic opportunity. Few of these migrants are able to find employment in the formal sector, which is dominated by men. As a consequence, women often represent the bulk of the informal-sector labor supply, working for low wages at unstable jobs with no employee or social security benefits. The increase in the number of single female migrants has also contributed to the rising proportion of urban households headed by women, which tend to be poorer, experience tighter resource constraints, and retain high fertility rates. The changing composition of migration flows has important economic and demographic implications for many urban areas of developing countries. 
Because members of female-headed households are generally restricted to low-productivity, informal-sector employment and experience higher dependency burdens, they are more likely to be poor and malnourished and less likely to obtain formal education, health care, or clean water and sanitation. Among the Brazilian poor, for example, male-headed households are four times more likely than female-headed households to have access to government-sponsored health services. School dropout rates among children from households headed by women are much higher, because children are more likely to be working to contribute to household income.

Many women run small business ventures, called microenterprises, that require little or no start-up capital and usually involve the marketing of homemade foodstuffs and handicrafts. Although women's restricted access to capital leads to high rates of return on their tiny investments, the extremely low capital-labor ratios confine women to low-productivity undertakings. Studies in Latin America and Asia have found that where credit is available to women working in informal-sector microenterprises, repayment rates have been as high as or higher than those for men. Because women are able to make more productive use of capital, their rates of return on investments often exceed those for men.

Despite the impressive record of these credit programs, few exist in Africa. The vast majority of institutional credit is channeled through formalsector agencies, and, as a result, African women generally find themselves ineligible for small loans. Government programs to enhance income in poor households will inevitably neglect the neediest households so long as they continue to focus on the formal-sector employment of men and the allocation of resources through formal-sector institutions. To solve the plight of 
poor urban women and their children, efforts must be made to integrate women into the economic mainstream. Ensuring that women benefit from development programs will require that women's special circumstances be considered in policy design.

The legalization and economic promotion of informal-sector activities, where the majority of the urban female labor force is employed, could greatly improve women's financial flexibility and the productivity of their ventures. However, to enable women to reap these benefits, African governments must repeal laws that restrict women's right to own property, to conduct financial transactions, or to limit their fertility. Likewise, barriers to women's direct involvement in technical training programs and extension services must be eradicated. Finally, the provision of affordable child care and family planning services would lighten the burden of African women's reproductive roles and permit them a greater degree of economic participation.

\section{URBAN UNEMPLOYMENT IN AFRICA}

As we have seen, one of the major consequences of the rapid urbanization process has been the burgeoning supply of job seekers in both the modern (formal) and traditional (informal) sectors of the urban economy. In most African countries, the supply of workers far exceeds the demand, the result being extremely high rates of unemployment and underemployment in urban areas. Table 8 provides some detailed data on urban unemployment for 12 African countries. Note that the table focuses solely on rates of open unemployment. Thus, it excludes the many more people who are chronically underemployed in the informal sector. The problem is, therefore, much more serious than even these data suggest. Also, because these statistics are from 
Table 8 Rates of urban and rural unemployment as a percentage of the active population in Africa, by country and year

\begin{tabular}{lclcc}
\hline & & & \multicolumn{2}{c}{ Unemployment } \\
\cline { 4 - 5 } Country & Year & Area & Urban & Rural \\
\hline Algeria & 1966 & Urban areas & 26.6 & na \\
Benin & 1968 & Urban areas & $13.0^{\mathrm{a}}$ & na \\
Burundi & 1963 & Capital city & $18.7^{\mathrm{a}}$ & na \\
Cameroon & 1962 & Largest city & $13.0^{\mathrm{a}}$ & na \\
& 1964 & Capital city & $17.0^{\mathrm{a}}$ & na \\
Côte d'Ivoire & 1963 & Capital city & $15.0^{\mathrm{a}}$ & na \\
Ghana & 1960 & Large towns & 12.0 & na \\
& 1970 & Two large cities & 9.0 & na \\
Kenya & $1968-69$ & Capital city & $10.0^{\mathrm{a}}$ & na \\
& $1968-69$ & Second-largest city & $14.0^{\mathrm{a}}$ & na \\
Morocco & 1960 & Urban areas & 20.5 & 5.4 \\
Nigeria & 1963 & Urban areas & 12.6 & na \\
Sierra Leone & 1967 & Capital city & 15.0 & na \\
Tanzania & 1965 & Urban areas & 7.0 & 3.9 \\
& 1971 & Seven towns & $5.0^{\mathrm{a}}$ & na \\
Zaire & 1967 & Capital city & 12.9 & na \\
\hline
\end{tabular}

na $=$ Data not available. $\quad{ }^{\mathrm{a}}$ Men only.

Source: Paul Bairoch (1973), Urban Unemployment in Developing Countries. Geneva: International Labour Organization, 1973. Page 49. Josef Gugler (1976), Internal Migration: The New World and the Third World. Eds. A. Richmond and D. Kubat. Beverly Hills, CA: Sage, 1976. Page 185.

the 1960s (more recent detailed data for these countries are nearly nonexistent), they are likely to show unemployment rates considerably below current levels (but see Table 9 for some 1980s data), because the sharp economic decline of the 1980s substantially increased urban unemployment and underemployment. ${ }^{6}$ Nevertheless, Table 8 indicates that even in the 1960s, 
Table 9 Percentage of open urban unemployment in four African countries

\begin{tabular}{llc}
\hline Country & Year & Average unemployed \\
\hline Botswana & 1985 & 31 \\
Kenya & 1986 & 16 \\
Liberia & 1984 & 13 \\
Tanzania & 1984 & 22 \\
\hline
\end{tabular}

Source: International Labour Organization (1989), World Labour Report, 1989. Geneva: International Labour Organization. Tables 1.7 and 1.12.

before the labor-force explosion and economic free-fall of the 1980s, African cities had very high rates of open urban unemployment. If scattered information on the substantial numbers of the urban labor force who were underemployed in part-time, informal-sector service activities had been included, the overall figures for urban surplus labor (both openly unemployed and underemployed) would have exceeded 30 percent in most countries. Moreover, had the focus here been on residents in the 15-24 age bracket (the majority of whom are recent migrants), the rate typically would have exceeded 50 percent. Because a major contributing factor to both high rates of urban growth and high rates of unemployment is rural-urban migration, investigating this critical issue in some detail is essential.

\section{MIGRATION AND DEVELOPMENT IN AFRICA}

For many years, rural-urban migration was viewed favorably in the economic development literature. Internal migration was thought to be a natural process in which surplus labor was gradually withdrawn from the rural sector to provide needed manpower for urban industrial growth. The 
process was deemed socially beneficial because human resources were being shifted from locations where their social marginal product was often assumed to be zero to places where this marginal product was not only positive but also rapidly growing as a result of capital accumulation and technological progress. This process was formalized in the Lewis theory of development. However, as Richard Jolly noted in 1970:

Far from being concerned with measures to stem the flow, the major interest of these economists (i.e., those who stressed the importance of labor transfer) was with policies that would release labor to increase the flow. Indeed, one of the reasons given for trying to increase productivity in the agricultural sector was to release sufficient labor for urban industrialization. How irrelevant most of this concern looks today. ${ }^{?}$

In contrast to the promigration viewpoint, three decades of African experience has made clear that rates of rural-urban migration have greatly exceeded rates of urban job creation and swamped the absorptive capacity of both formal-sector industry and urban social services. Migration can no longer be casually viewed by economists as a beneficent process necessary to solve problems of growing urban labor demand. On the contrary, migration today remains a major factor contributing to the phenomenon of urban surplus labor; a force that continues to exacerbate already serious urban unemployment problems caused by the growing economic and structural imbalances between African urban and rural areas.

Migration exacerbates these rural-urban structural imbalances in two direct ways. First, on the supply side, internal migration disproportionately increases the growth rate of urban job seekers relative to urban population 
growth, which itself stands at historically unprecedented levels, because of the high proportion of well-educated young people in the migrant system. Their presence tends to swell the urban labor supply while depleting the rural countryside of valuable human capital. Second, on the demand side, urban job creation is generally more difficult to accomplish than rural job creation because of the need for substantial complementary resource inputs for most jobs in the industrial sector. Moreover, the pressures of rising urban wages and compulsory employee fringe benefits in combination with the unavailability of appropriate, more labor-intensive production technologies means that a rising share of modern-sector output growth is accounted for by increases in labor productivity. Together this rapid supply increase and lagging demand (what many now refer to as "jobless growth") tend to convert a short-run problem of resource imbalances into a long-run situation of chronic and rising urban surplus labor.

The impact of migration on the African development process is much more pervasive than its obvious exacerbation of urban unemployment and underemployment. In fact, the significance of the migration phenomenon throughout much of Africa lies not necessarily in the process itself or even in its impact on the sectoral allocation of human resources. Rather, its significance lies in its implications for economic growth in general and for the character of that growth, particularly in its distributional manifestations.

Migration in excess of job opportunities is both a symptom of and a contributor to African underdevelopment. Understanding the causes, determinants, and consequences of internal rural-urban labor migration is thus central to understanding the nature and character of the development process and to formulating policies to influence this process in socially desirable ways. 
A simple yet crucial step in underlining the centrality of the migration phenomenon is to recognize that any economic and social policy that affects rural and urban real incomes will influence the migration process directly or indirectly. This process will, in turn, tend to alter the pattern of sectoral and geographic economic activity, income distribution, and even population growth. Because all economic policies have direct and indirect effects on the level and growth of either urban or rural incomes or of both, they all will have a tendency to influence the nature and magnitude of the migration stream. Although some policies may have a more direct and immediate impact (for example, wages and employment-promotion programs), many others, even though less obvious, may in the long run be no less important. These policies, for example, would include land-tenure arrangements; commodity pricing; credit allocation; taxation; export promotion; import substitution; commercial and exchange-rate policies; the geographic distribution of social services; public-investment programs; dealings with private foreign investors; population and family planning programs; the structure, content, and orientation of the educational system; the functioning of labor markets; and international technology transfer and the location of new industries.

Recognition of the central importance of rural-urban migration is clearly necessary, as is integration of the two-way relationship between migration and population distribution on the one hand and economic variables on the other into a more comprehensive framework designed to improve development-policy formulation. In addition, we need to understand better not only why people move and what factors are most important in their decisionmaking process but also what the consequences of migration are for rural and urban economic and social development. If all development poli- 
cies affect migration and are affected by it, which are the most significant, and why? What are the policy options and trade-offs among different and sometimes competing objectives (for example, curtailing internal migration and expanding educational opportunities in rural areas)?

\section{INTERNAL MIGRATION IN AFRICA}

An understanding of the causes and determinants of rural-urban migration and the relationship between migration and relative economic opportunities in urban and rural areas is central to any analysis of African employment problems. Because migrants comprise a significant proportion of the urban labor force in most African nations, the magnitude of rural-urban migration has been and will continue to be a principal determinant of the supply of new job seekers. Therefore, the migration process must be understood before the nature and causes of urban unemployment can be comprehended. Government policies intended to ameliorate the urban unemployment problem must be based, in the first instance, on knowledge of who comes to town and why.

\section{The migration process}

The factors influencing the decision to migrate are varied and complex. Because migration is a selective process affecting individuals with certain economic, social, educational, and demographic characteristics, the relative influence of economic and noneconomic factors may vary not only between nations and regions but also within defined geographic areas and populations. Much of the early research on migration tended to focus on 
social, cultural, and psychological factors while recognizing, but not evaluating carefully, the importance of economic variables. Emphasis has been placed on five broad areas: (1) social factors, including the desire of migrants to break away from traditional constraints of social or kinship affiliations; (2) physical factors, including climate and meteorological disasters like floods and droughts, as well as wars and rural violence; (3) demographic factors, including reduction in mortality rates and concomitant high rates of rural population growth; (4) cultural factors, including the security of African urban extended-family relationships and the allure of modern urban amenities; (5) communication factors, including improved transportation, urban-oriented educational systems, and the modernizing impact of radio, television, and cinema.

All these noneconomic factors are, of course, relevant. However, widespread agreement now exists among economists and noneconomists that rural-urban migration can be explained primarily as the result of economic factors. These include not only the standard push from subsistence agriculture and the pull of relatively high urban wages but also the potential push back toward rural areas as a result of high urban unemployment.

\section{Migrant characteristics}

The main characteristics of migrants are conveniently divided into three broad categories: demographic, educational, and economic.

Demographic characteristics. Urban migrants in developing countries tend to be young men and women between the ages of 15 and 24. Various studies in Africa and Asia have provided quantitative evidence of this phenomenon in Kenya, Tanzania, Ghana, Nigeria, India, Thailand, South Ko- 
rea, and the Philippines. In recent years, the proportion of migrating women has increased as their educational opportunities have expanded. This increase, substantial in many countries, has been particularly evident in Latin America, Southeast Asia, and West Africa. In fact, women now constitute the majority of the migration stream in Latin America, largely as a result of the region's relatively advanced state of urbanization compared with other developing regions. ${ }^{8}$ Basically, there are two types of female migration: the "associational" migration of wives and daughters accompanying the "primary" male migrant, and the migration of unattached women. The latter type of migration is increasing most rapidly in Africa.

Educational characteristics. One of the most consistent findings of rural-urban migration studies is the positive correlation between educational attainment and migration. A clear association is found between the level of completed education and the propensity to migrate: People with more years of schooling, everything else being equal, are more likely to migrate than those with less schooling. In a comprehensive study of migration in Tanzania by Barnum and Sabot, for example, the relationship between education and migration was clearly documented, especially in terms of the impact of declining urban employment opportunities on the educational characteristics of migrants. ${ }^{9}$ Secondary-school dropouts were found to constitute a rising proportion of the migration stream. The explanation that Barnum and Sabot offered was that limited urban employment opportunities were being rationed by educational levels, and only workers with at least some secondary education had a chance of finding a job. Those with only a primaryschool education were finding it difficult to secure employment, and hence their proportionate numbers in the migrant stream began to decline. 
Economic characteristics. For many years, the largest proportion of urban migrants were poor, landless, and unskilled individuals whose rural opportunities were, for the most part, nonexistent. In colonial Africa, seasonal migration was predominant, with migrants from various income levels seeking short-term urban jobs. Recently, however, with the emergence of a stabilized, modern industrial sector in most African urban areas, the situation has changed. Migrants, both male and female, seem to come from all socioeconomic strata, with the majority of them being very poor only because most rural inhabitants are poor.

\section{AN ECONOMIC THEORY OF AFRICAN RURAL-URBAN MIGRATION}

Historically, the economic development of Western Europe and the United States was closely associated with, and in fact defined in terms of, the movement of labor from rural to urban areas. For the most part, with a rural sector dominated by agricultural activities and an urban sector focusing on industrialization, overall economic development in these countries was characterized by the gradual reallocation, both internal and international, of labor from agriculture into industry through rural-urban migration. Urbanization and industrialization were essentially synonymous. This historical model served as a blueprint for developing nations, as evidenced, for example, by the original Lewis theory of labor transfer.

However, the overwhelming evidence of the past few decades, when developing nations in general and African countries in particular witnessed a massive migration of their rural populations into urban areas despite rising levels of urban unemployment and underemployment, lessens the validity of 
the Lewis two-sector model of development. ${ }^{10}$ An explanation of the phenomenon, as well as policies to address the resulting problems, must be sought elsewhere. In a series of articles published during the past two decades the author has developed a theory of rural-urban migration (the Todaro migration model) to explain the apparently paradoxical relationship of accelerated rural-urban migration in the context of rising urban unemployment. ${ }^{11}$

Starting from the assumption that migration is primarily an economic phenomenon, which for the individual migrant can be a rational decision to make despite the existence of urban unemployment, this model postulates that migration proceeds in response to urban-rural differences in expected income rather than actual earnings. The fundamental premise is that migrants and their families consider the various labor-market opportunities available to them in the rural and urban sectors and choose the one that maximizes their expected gains from migration. Expected gains are measured by the difference in real incomes between rural and urban work and the probability of a new migrant's obtaining an urban job. A schematic framework showing how the varying factors interact to affect the migration decision in Africa is given in Figure 2.

In essence, the theory assumes that members of the labor force, both actual and potential, compare their expected incomes for a given time horizon in the urban sector (the difference between returns and costs of migration) with prevailing average rural incomes and migrate if the former exceeds the latter.

Consider the following illustration. Suppose that the average unskilled or semiskilled rural worker has a choice between working his own or some else's land for an annual average real income of, say, 50 units and migrating 
Figure 2 Schematic framework for analyzing the migration decision in Africa

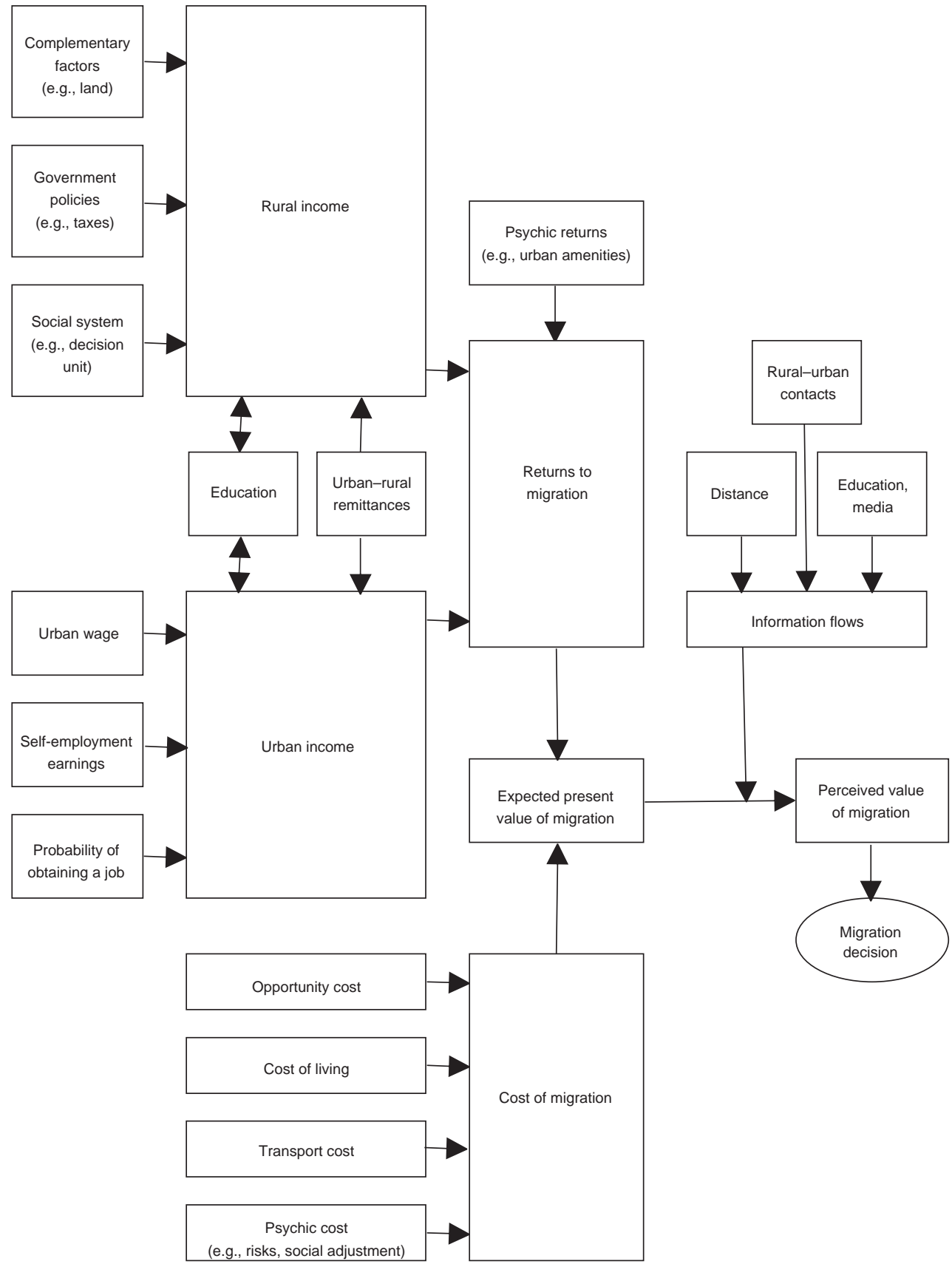

Source: Derek Byerlee (1974), "Rural-urban migration in Africa: Theory, policy, and research implications," International Migration Review 3: 553. 
to the city, where, with his skill and educational background, he might obtain wage employment yielding an annual real income of 100 units. The more commonly used economic models of migration, which place exclusive emphasis on the income-differential factor as the determinant of the decision to migrate, would indicate a clear choice in this situation. The worker should seek the higher-paying urban job. However, these migration models were developed largely in the context of advanced industrial economies and, therefore, implicitly assume the existence of full or nearly full employment. In a full-employment environment, the decision to migrate can be based solely on the desire to secure the highest-paid job wherever it becomes available. Simple economic theory would indicate that such migration should lead to a reduction in wage differentials through the interaction of the forces of supply and demand, in areas of both emigration and immigration.

Unfortunately, such an analysis is not realistic in the context of the institutional and economic framework of most African nations. First, these countries are beset by a chronic unemployment problem, so that a typical migrant cannot expect to secure a high-paying urban job immediately. In fact, on entering the urban labor market, many uneducated, unskilled migrants are more likely to become totally unemployed or be forced to seek casual and part-time employment as vendors, hawkers, repairmen, and itinerant day laborers in the traditional (informal) sector, where ease of entry, small scale of operation, and relatively competitive price and wage determination prevail. In the case of migrants with considerable human capital in the form of a secondary or university certificate, opportunities are much better, and many will find formal-sector jobs relatively quickly. But these individuals constitute only a small proportion of the total migration stream. Consequently, in deciding to migrate, the probabilities and risks of being 
unemployed or underemployed for a considerable period of time must be balanced against the positive urban-rural real income differential. That a typical African migrant can expect to earn twice as great an annual real income in an urban area as he can in a rural environment may be of little consequence if the probability of his securing the higher-paying job within, for example, a oneyear period is one chance in five. Thus, the probability of his being successful in securing the higher-paying urban job is 20 percent, and, therefore, his expected urban income for the one-year period is in fact 20 units, not the 100 units that an urban worker in a full-employment environment would expect to receive. So, with a one-period time horizon and a probability of success of 20 percent, the decision to seek an urban job would be irrational, even though the differential between his urban and rural earning capacity is 100 percent. However, if his probability of success were 60 percent and his expected urban income, therefore, were 60 units, the migrant would be entirely rational within his one-period time horizon to try his luck in the urban area, even though urban unemployment may be extremely high.

If we approach the situation by assuming a considerably longer time horizon - a more realistic assumption because the vast majority of migrants are between the ages of 15 and 24-the decision to migrate should be represented on the basis of a longer-term, more permanent income calculation. If the migrant anticipates a relatively low probability of finding regular-wage employment in the initial period, but expects this probability to increase over time as he is able to broaden his urban contacts, his decision to migrate would still be rational, even though his expected urban income during the initial period or periods might be lower than his expected rural income. As long as the present value of the net stream of expected urban income over the migrant's 
planning horizon exceeds that of his expected rural income, the decision to migrate is justifiable. This, in essence, is the process portrayed in the figure.

Rather than equalizing urban and rural wage rates, as would be the case in a competitive model, we see that rural-urban migration in this model acts as an equilibrating force that equates rural and urban expected incomes. For example, if average rural income is 60 units and urban income is 120 units, a 50 percent urban unemployment rate would be necessary before further migration would no longer be profitable. Because expected incomes are defined in terms of both wages and employment probabilities, continued migration can be profitable despite the existence of sizable rates of urban unemployment. In this example, migration would continue even if the urban unemployment rate were 30 to 40 percent. Conversely, if the urban-rural wage gap declines, migration could continue to accelerate if the urban unemployment rate also declines.

\section{A diagrammatic presentation}

This process of achieving an unemployment equilibrium between urban expected wages and average rural income rather than an equalized ruralurban wage as in the traditional neoclassical free-market model can also be explained by a diagrammatic portrayal of the basic Todaro model, as shown in Figure $3 .{ }^{12}$ Assume only two sectors, rural agriculture and manufacturing. The demand for labor (the marginal product of labor curve) in agriculture is given by the negatively sloped line $A A^{\prime}$. Labor demand in manufacturing is given by $M M^{\prime}$ (reading from right to left). The total labor force is given by line $O_{A} O_{M}$. In a neoclassical, flexible-wage, full- employment market economy, 
the equilibrium wage would be established at $W_{A}^{*}=W_{M}^{*}$, with $O_{A} L_{A}^{*}$ workers in agriculture and $O_{M} L_{M}^{*}$ workers employed in urban manufacturing. All available workers are therefore employed.

But what if urban wages are institutionally determined at a level $\bar{W}_{M}$, which is at a considerable distance above $W_{A}^{*} ?^{13}$ The validity of this assumption was recently confirmed in a careful econometric study of urban formalsector wage determination in Ghana. ${ }^{14}$ If, for the moment, we continue to assume that there is no unemployment, $O_{M} L_{M}$ workers would obtain urban

Figure 3 The Todaro migration model

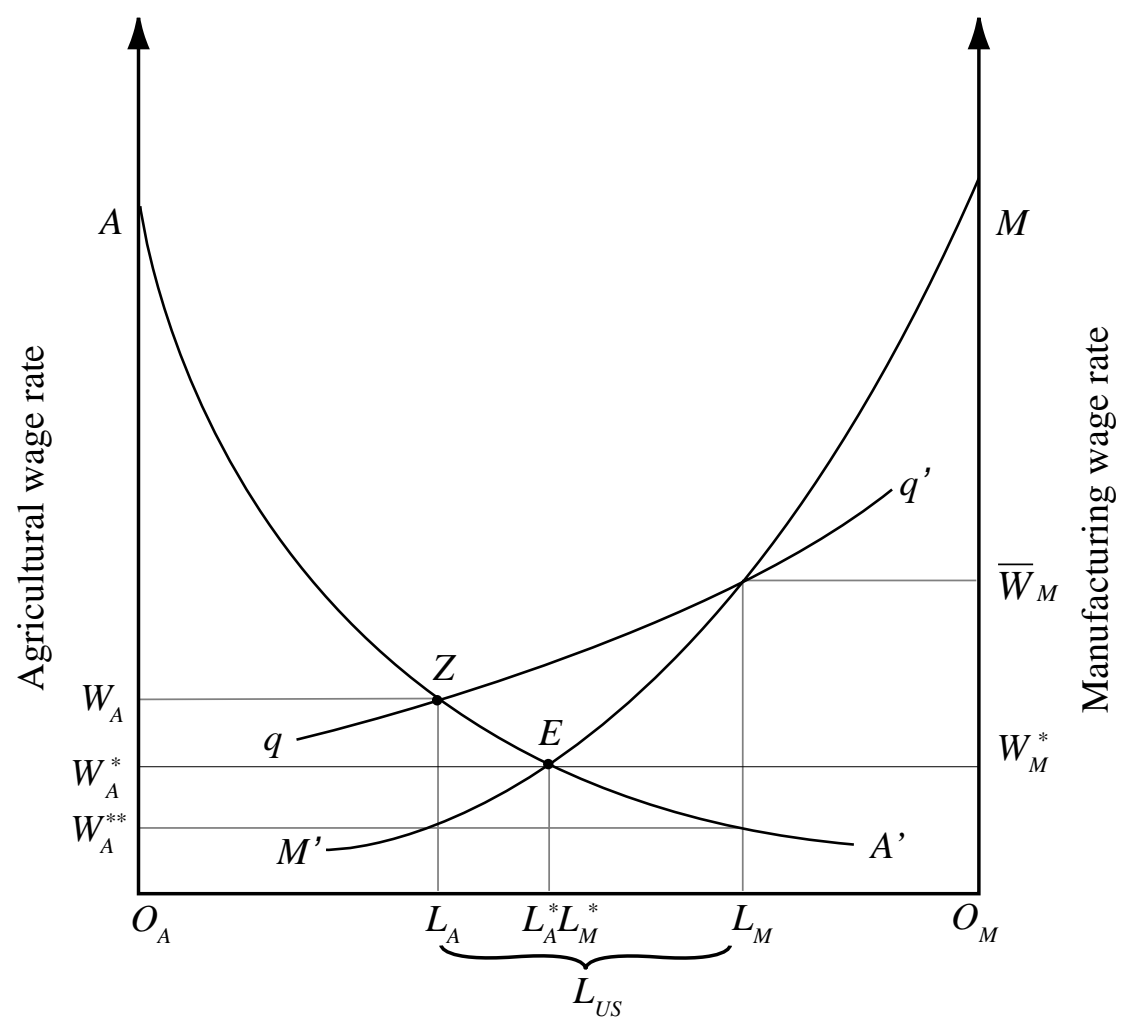


jobs, and the rest, $O_{A} L_{M}$, would have to settle for rural employment at $O_{A} W_{A}^{* *}$ wages (below the free-market level of $O_{A} W_{A}^{*}$ ). Now we have an urban-rural real wage gap of $\bar{W}_{M}-W_{A}^{* * *}$, with $\bar{W}_{M}$ institutionally fixed. If rural workers were free to migrate (as they are almost everywhere except in parts of China), then despite the availability of only $O_{M} L_{M}$ jobs, they are willing to take their chances in the urban job lottery. If their chance (probability) of securing one of these favored jobs is expressed by the ratio of employment in manufacturing, $L_{M}$, to the total urban labor pool, $L_{U S}$, then the expression

$$
W_{A}=\frac{L_{M}}{L_{U S}}\left(\bar{W}_{M}\right)
$$

shows the probability of urban job success necessary to equate agricultural income $W_{A}$ with expected urban income $\left(L_{M} / L_{U S}\right)\left(\bar{W}_{M}\right)$, thus causing a potential migrant to be indifferent to job locations. The locus of such points of indifference is given by the $q q$ ' curve in the figure. ${ }^{15}$ The new unemployment equilibrium now occurs at point $Z$, where the actual urban-rural wage gap is $\bar{W}_{M}-W_{A}, O_{A} L_{A}$ workers are still in the agricultural sector, and $O_{M} L_{M}$ of these workers have modern (formal)-sector jobs paying $\bar{W}_{M}$ wages.

The rest $L_{U S}=O_{M} L_{A}-O_{M} L_{M}$ are either unemployed or engaged in lowincome, informal-sector activities. This explains the existence of urban unemployment and the private economic rationality of continued rural-urban migration despite high unemployment. However, although migrating to the city may be rational from a cost-benefit perspective for an individual despite high urban unemployment, it can, as we shall soon discover, be very costly socially. Finally, if instead of assuming that all urban migrants are the 
same, we incorporate the reality of different levels of human capital (education), we can understand why a higher proportion of the rural educated migrate than do the uneducated-because they have a better chance (a higher probability) of earning higher urban wages than do unskilled migrants.

To sum up, the Todaro migration model has four basic characteristics:

1 Migration is stimulated primarily by rational economic considerations of relative benefits and costs.

2 The decision to migrate depends on expected rather than actual urban-rural real wage differentials, where the expected differential is determined by the interaction of two variables, the actual urban-rural wage differential and the probability of obtaining employment in the urban sector.

3 The probability of obtaining an urban job is directly related to the urban employment rate and is thus inversely related to the urban unemployment rate.

4 Migration rates in excess of job-opportunity growth rates are not only possible but also rational and even likely in the face of wide urban-rural expected-income differentials. High rates of urban unemployment are, therefore, inevitable outcomes of the serious imbalance of economic opportunities between urban and rural areas in most African countries.

\section{Policy implications}

Although this theory might, at first, seem to devalue the critical importance of rural-urban migration by portraying it as an adjustment mechanism by which workers allocate themselves between rural and urban labor mar- 
kets, it does have important policy implications for African development strategy with regard to wages and incomes, rural development, and industrialization.

First, imbalances in urban-rural employment opportunities caused by the urban bias of many African development strategies must be reduced. Because migrants are assumed to respond to differentials in expected incomes, it is vitally important that imbalances between economic opportunities in rural and urban sectors be minimalized. Permitting real urban wage rates to rise at a greater pace than average rural incomes (or, indeed, to fall, as in the 1980s, at a slower pace) will stimulate further rural-urban migration in spite of rising levels of urban unemployment. This heavy influx of people into urban areas not only gives rise to socioeconomic problems in the cities but eventually may also create problems of labor shortages in rural areas, especially during the busy seasons. These social costs of migration may exceed its benefits to individuals.

Second, urban job creation is an insufficient solution for the urban unemployment problem. The traditional (Keynesian) economic solution to urban unemployment (the creation of more urban modern-sector jobs without simultaneous attempts to improve rural incomes and employment opportunities) can result in the paradoxical situation in which more urban employment leads to higher levels of urban unemployment. Once again, the imbalance in expected income-earning opportunities is the crucial concept. Because migration rates are assumed to respond positively to both higher urban wages and higher urban employment opportunities (or probabilities), it follows that for any given positive urban-rural wage differential (in most of Africa, urban wages are three to four times greater than rural wages), 
higher urban employment rates will widen the expected differential and induce even higher rates of rural-urban migration. For every new job created, two or three migrants who were productively occupied in rural areas may come to the city. Thus, if 100 new jobs are created, as many as 300 new migrants may seek them and, therefore, 200 more urban dwellers will be unemployed. A policy designed to reduce urban unemployment may lead not only to higher levels of urban unemployment but also to lower levels of agricultural output as a result of induced migration.

Third, indiscriminate educational expansion will lead to further migration and unemployment. The Todaro model thus has important (and unconventional) policy implications for curtailing investment in excessive educational expansion, especially at the higher levels. The heavy influx of rural migrants into urban areas at rates much in excess of new employment opportunities has necessitated a rationing device in the selection of new employees. Although within each educational group such selection may be largely random, many observers have noted that employers tend to use the number of years of completed schooling as the typical rationing device. For the same wage, they will hire people with more education in preference to those with less, even though higher education may not contribute to better job performance. Formerly, those with a primary education could hold jobs as sweepers, messengers, filing clerks, and the like, whereas now such jobs require secondary training; those jobs formerly requiring a secondary certificate (positions for clerks, typists, bookkeepers, and the like) now require a university degree. Therefore, for any given urban wage, if the probability of success in securing a modern-sector job is higher for people with more education, their expected-income differential will also be higher, and they will be more 
likely to migrate to the cities. Thus, the basic Todaro model provides an economic rationale for the observation that in most less-developed countries, rural inhabitants with more education are more likely to migrate than are those with less.

From the viewpoint of educational policy, the prediction is safe that as job opportunities become scarce in relation to the number of applicants, students will experience increasing pressure to proceed farther up the educational ladder. The private demand for education, which in many ways is a derived demand for urban jobs, will continue to exert tremendous pressure on African governments to invest in postprimary school facilities. But for many of these students, the specter of joining the ranks of the educated unemployed becomes more of a reality with each passing year. Government overinvestment in postprimary educational facilities often turns out to be an investment in idle human resources.

Fourth, wage subsidies and traditional scarcity-factor pricing can be counterproductive. A standard economic policy prescription for generating urban employment opportunities is to eliminate factor-price distortions by using "correct" prices, perhaps implemented by wage subsidies (fixed government subsidies to employers for each worker employed) or direct government hiring. Because actual urban wages generally exceed the market or "correct" wage as a result of a variety of institutional factors, the argument is often made that the elimination of wage distortions through market-price adjustments or a subsidy system will encourage more labor-intensive modes of production. Although such policies can do this, they can also lead to higher levels of unemployment in accordance with the argument advanced here about induced migration. The overall welfare impact of a wage-subsidy policy 
when both the rural and urban sectors are taken into account is not immediately clear. Much will depend on the level of urban unemployment, the size of the urban-rural expected-income differential, and the employment elasticity of induced migration as more urban jobs are created. ${ }^{16}$

Finally, programs of integrated rural development should be encouraged. Policies that operate only on the demand side of the urban employment picture, such as wage subsidies, direct government hiring, elimination of factor-pricing distortions, and employer tax incentives, are probably far less effective in the long run in alleviating the unemployment problem than are policies designed directly to regulate the supply of labor to urban areas. Clearly, however, some combination of both kinds of policies is most desirable.

Policies of rural development are crucial to this aim. Many informed observers agree on the central importance of African rural and agricultural development to the solution of the urban unemployment problem. Most proposals call for the restoration of a proper balance between rural and urban incomes and for changes in government policies that currently give development programs a strong bias toward the urban industrial sector (for example, policies for the provision of health, education, and social services).

Given the prevailing urban bias and thus the political difficulties of reducing urban-rural real-wage differentials, the need to expand urban employment opportunities continuously through judicious investments in smalland medium-scale labor-intensive industries, and given the inevitable growth of the urban industrial sector, every effort must be made to broaden the economic base of the rural economy. The present unnecessary economic incentives for rural-urban migration must be minimized through creative and welldesigned programs of integrated rural development. These should focus on 
both farm and nonfarm income generation, employment growth, delivery of health-care services, educational improvement, infrastructure development (electricity, water, roads, and so forth), and the provision of other rural amenities. Successful rural development programs adapted to the socioeconomic and environmental needs of diverse African countries seem to offer the only viable long-run solution to the problem of excessive rural-urban migration.

To assert, however, that an urgent need exists for policies designed to curb the excessive influx of rural migrants is not to imply an attempt to reverse what some observers have called inevitable historical trends. Rather, the implication of the Todaro migration model is that a growing need exists for a policy package that does not exacerbate these historical trends toward urbanization by artificially creating serious imbalances in economic opportunities between urban and rural areas.

\section{SUMMARY AND CONCLUSIONS}

In this essay, we have looked at possible policy approaches designed to improve the serious migration and employment situation in African countries. In conclusion, a summary is presented below of what appears to be the growing consensus of most economists on the shape of a comprehensive migration and employment strategy. ${ }^{17}$ This consensus has six key elements:

1 Creating an appropriate rural-urban economic balance. A more appropriate balance between rural and urban economic and noneconomic opportunities appears to be indispensable to ameliorating urban and rural unemployment problems and to slowing the pace of rural-urban migration. The main thrust of this activity 
should lie in the integrated development of the rural sector, the spread of small-scale industries throughout the countryside, and the reorientation of economic activity and social investments toward rural areas.

2 Expansion of small-scale, labor-intensive industries. The composition or "product mix" of output has obvious effects on the magnitude (and, in many cases, the location) of employment opportunities, because some products (often basic consumer goods) require more labor per unit of output and per unit of capital than do others. Expansion of these mostly small-scale and labor-intensive industries in both urban and rural areas can be accomplished in two ways: directly, through government investment and incentives, particularly for activities in the urban informal sector; and indirectly, through income redistribution (either directly or from future growth) to the rural poor, whose structure of consumer demand is both less import-intensive and more labor-intensive than that of the better-off.

3 Elimination of factor-price distortions. Ample evidence exists to demonstrate that correcting factor-price distortions primarily by eliminating various capital subsidies and curtailing the growth of urban wages through market-based pricing would increase employment opportunities and make better use of scarce capital resources, but by how much or how quickly these policies would work is not clear. Moreover, their migration implications would have to be ascertained. Correct pricing policies by themselves are insufficient to alter the present employment situation significantly. 
4 Choosing appropriate labor-intensive technologies of production. One of the principal factors inhibiting the success of any long-run program for creating employment in urban industry and rural agriculture is the almost complete technological dependence of African nations on imported (typically labor-saving) machinery and equipment from developed countries. Both domestic and international efforts must be made to reduce this dependence by developing technological research and adaptation capacities in the countries themselves-ideally as a cooperative and coordinated regional endeavor. Such efforts might first be linked to the development of small-scale, labor-intensive methods of meeting rural infrastructure needs, including roads, irrigation and drainage systems, and essential health and educational services. In this area, scientific and technological assistance from developed countries and their nongovernmental organizations could prove extremely helpful.

5 Modifying the direct linkage between education and employment. The emergence of the phenomenon of the educated unemployed is calling into question the appropriateness of the massive quantitative expansion of African educational systems, especially at higher levels. Formal education has become the rationing tunnel through which all prospective jobholders must pass. As modern-sector jobs multiply more slowly than do the numbers of persons leaving the educational tunnel, extending the length of the tunnel and narrowing its exit become necessary. One way to moderate the excessive demand for additional years of schooling (which, in reality, is a demand for modern-sector jobs) would be for African governments, 
often the largest employers, to base their hiring practices and their wage structures on other criteria. Moreover, the creation of attractive economic opportunities in rural areas would make redirecting educational systems toward the needs of rural development easier. At present, many African educational systems, being transplants of colonial systems, are oriented toward preparing students to function in a small modern sector employing at the most 20 to 30 percent of the labor force. Many of the necessary skills for development thus remain largely neglected.

6 Reducing population growth through reductions in absolute poverty and inequality, particularly for women, along with the expanded provision of family planning and rural health services. Clearly, any long-run solution to African employment and urbanization problems must involve a lowering of current high rates of population growth. Even though the labor-force size for the next two decades is already determined by today's birth rates, the hidden momentum of population growth applies equally to labor-force growth. Together with the demand policies identified in points 1 through 5, reducing rural population growth with its delayed impact on the urban labor supply provides an essential ingredient in any strategy to combat the severe employment problems that African countries face now and in future years.

\section{Notes}

1. Many of the data on urbanization, migration, and occupational structure for developing countries in general and sub-Saharan Africa in 
particular are less than desirable from a research perspective. Nevertheless, they do provide general orders of magnitude from which comparisons can be drawn.

2. Robert S. McNamara. 1984. "The population problem: Time bomb or myth?" Foreign Affairs 62: 1,107-1,131. For additional information on the problems of rapid urban population growth, see Bertrand Renaud, 1981, National Urbanization Policy in Developing Countries, New York: Oxford University Press. A less foreboding viewpoint is expressed in Jeffrey G. Williamson, "Migration and urbanization," in Hollis B. Chenery and T.N. Srinivasan (eds.), 1988, Handbook of Development Economics, vol. 1, Amsterdam: North Holland. Pp. 426-465.

3. United Nations Population Fund. 1991. Population, Resources, and the Environment. New York: United Nations. P. 61.

4. United Nations Population Division. 1988. World Population Monitoring, 1987. New York: United Nations,. These results were reiterated in the Programme of Action of the 1994 International Conference on Population and Development, paragraph 91.

5. For a concise review of this debate, see Cathy A. Rakowski, 1994, "Convergence and divergence in the informal sector debate: A focus on Latin America, 1984-92." World Development 22: 501-516.

6. For evidence of the deteriorating urban employment situation in subSaharan Africa during the 1980s, see the International Labour Organization's World Labour Reports for 1988 and 1989; Dharam Ghai, 1987, 
Economic Growth, Structural Change and Labour Absorption in Africa, 1960-85, Discussion Paper No. 1, Geneva: United Nations Research Institute for Human Development; and, especially, Charles M. Becker, Andrew M. Hammer, and Andrew R. Morrison, 1994, Beyond Urban Bias in Africa: Urbanization in an Era of Structural Adjustment, Portsmouth, NH: Heinemann.

7. Richard Jolly. 1970. "Rural-urban migration: Dimensions, causes, issues and policies," in Prospects for Employment Opportunities in the Nineteen Seventies. Ed. Richard Jolly. Cambridge: Cambridge University Press, P. 4.

8. Pamela Brigg. 1971. Migration to Urban Areas: A Survey, World Bank Staff Working Paper, No. 107. Washington, DC: World Bank; United Nations, 1988, The Prospects of World Urbanization, New York: United Nations.

9. Henry N. Barnum and Richard H. Sabot. 1975. Migration, Education and Urban Surplus Labour. OECD Development Center Employment Series Monograph. Paris: Organization for Economic Cooperation and Development.

10. Although the rate of rural-urban migration slowed during the 1980s, especially in Latin America and sub-Saharan Africa, as a result of declining urban real wages and fewer formal-sector employment opportunities, the actual number of migrants continued to expand.

11. See, for example, Michael P. Todaro, 1969, "A model of labor migration and urban unemployment in less developed countries," American 
Economic Review 59: 138-148, and John R. Harris and Michael P. Todaro, 1970, "Migration, unemployment, and development: A twosector analysis," American Economic Review 60: 126-142.

12. This graph was first introduced in W. Max Corden and Ronald Findlay, 1975, "Urban unemployment, intersectoral capital mobility, and development policy," Economica 42: 59-78, and reproduced and described in Jeffrey G. Williamson, "Migration and urbanization," pp. 443-445 (see note 2 for complete reference).

13. Whereas the Todaro model focuses on the institutional determinants of urban wage rates above the equilibrium wage, several other authors have sought to explain this phenomenon by focusing on the high costs of labor turnover in urban areas and the notion of an efficiency wagean above-equilibrium urban wage that enables employers to secure a higher-quality work force and greater productivity on the job. For a review of these various models, see Joseph Stiglitz, 1974, "Alternative theories of wage determination and unemployment in LDCs: The labor turnover model," Quarterly Journal of Economics 88, and Janet L.Yellen, 1984, "Efficiency wage models of unemployment," American Economic Review 74.

14. Francis Teal. 1996. "The size and sources of economic rents in a developing country manufacturing labour market," Economic Journal 106: 963-976.

15. Note that $q q^{\prime}$ 'is a rectangular hyperbola, a unitary-elasticity curve showing a constant urban wage bill; that is, $L_{M} \times W_{M}$ is fixed. 
16. For a formal treatment of the determinants of induced migration, see Michael P. Todaro, 1976, "Urban job expansion, induced migration and rising unemployment: A formulation and simplified empirical test for LDCs," Journal of Development Economics 3: 211-225.

17. See, for example, Gary S. Fields, 1987, "Public policy and the labor market in less developed countries," in David P. Newberry and Nicholas Stern (eds.), The Theory of Taxation for Developing Countries, New York: Oxford University Press; Charles M. Becker, Andrew M. Hammer, and Andrew R. Morrison, 1994, Beyond Urban Bias in Africa, chapters 4-7 (see note 6 for complete reference); David Turnham, 1993, Employment and Development: A New Review of Evidence, Paris: Organization for Economic Cooperation and Development, pp. 245253; and Paul P. Streeten, 1994, Strategies for Human Development: Global Poverty and Unemployment, Copenhagen: Handelshøjskolens Forlag, 1994, pp. 50-64. 


\title{
POLICY RESEARCH DIVISION WORKING PAPERS
}

\author{
Recent Back Issues
}

1995

* 70 Sajeda Amin, John Cleland, James F. Phillips, and Gholam Mostafa Kamal, "Socioeconomic change and the demand for children in rural Bangladesh."

71 John Bongaarts, "The role of family planning programs in contemporary fertility transitions."

72 Geoffrey McNicoll, "On population growth and revisionism: Further questions."

73 James F. Phillips, Mian Bazle Hossain, and Mary Arends-Kuenning, "The longterm demographic role of communitybased family planning in rural Bangladesh."

74 Cynthia B. Lloyd, "Household structure and poverty: What are the connections?"

75 Sajeda Amin, "The poverty-purdah trap in rural Bangladesh: Implications for women's roles in the family."

76 Martin Brockerhoff, "Child mortality in East Africa: The impact of preventive health care."
77 Thomas K. LeGrand and James F. Phillips, "The effect of fertility reductions on infant and child mortality: Evidence from Matlab in rural Bangladesh."

78 Cynthia B. Lloyd and Ann K. Blanc, "Children's schooling in sub-Saharan Africa: The role of fathers, mothers, and others."

79 Geoffrey McNicoll, "Demography in the unmaking of civil society."

80 John Bongaarts, "Global trends in AIDS mortality."

81 Barbara Mensch, Mary ArendsKuenning, Anrudh Jain, and María Rosa Garate, "Meeting reproductive goals: The impact of the quality of family planning services on unintended pregnancy in Peru."

82 Mark Montgomery, Aka Kouamé, and Raylynn Oliver, "The tradeoff between the number of children and their schooling: Evidence from Côte d'Ivoire and Ghana." 
83 Sajeda Amin, Ian Diamond, and Fiona Steele, "Contraception and religious practice in Bangladesh."

84 John B. Casterline, Aurora E. Perez, and Ann E. Biddlecom, "Factors underlying unmet need for family planning in the Philippines."

85 Geoffrey McNicoll, "Governance of fertility transition: Regularity and duress."

86 John Bongaarts, "Population pressure and the food supply system in the developing world."

87 Sajeda Amin, "Family structure and change in rural Bangladesh."

88 John Bongaarts and Susan Cotts Watkins, "Social interactions and contemporary fertility transitions."
89 Cynthia B. Lloyd and Mark R. Montgomery, "The consequences of unintended fertility for investments in children: Conceptual and methodological issues."

* 90 Zeba Sathar and Sonalde Desai, "Work patterns in rural Pakistan: Intersections between gender, family, and class."

* 91 Mark R. Montgomery, "Learning and lags in mortality perceptions."

92 Ann E. Biddlecom, John B. Casterline, and Aurora E. Perez, "Men's and women's views of contraception."

* No longer available 
93 James F. Phillips, Fred N. Binka, Martin Adjuik, Alex Nazzar, and Kubaze Frank Adazu, "The determinants of contraceptive innovation: A case-control study of family planning acceptance in a traditional African society."

94 John Bongaarts and Sajeda Amin, "Prospects for fertility decline and implications for population growth in South Asia."

95 Barbara S. Mensch and Cynthia B. Lloyd, "Gender differences in the schooling experiences of adolescents in low-income countries: The case of Kenya."

96 Martin Brockerhoff and Ellen Brennan, "The poverty of cities in the developing world."

97 Carol E. Kaufman, "Reproductive control in South Africa."

98 John Bongaarts, "Trends in unwanted childbearing in the developing world."
99 Mary Arends-Kuenning, "How do family planning workers' visits affect women's contraceptive behavior in Bangladesh?"

100 Mark R. Montgomery and Cynthia B. Lloyd, "Excess fertility, unintended births, and children's schooling."

101 Mary Arends-Kuenning, "The equity and efficiency of doorstep delivery of contraceptives in Bangladesh."

102 Sajeda Amin, Ian Diamond, Ruchira T. Naved, and Margaret Newby, "Transition to adulthood of female factory workers: Some evidence from Bangladesh."

103 Margaret E. Greene and Ann E. Biddlecom, "Absent and problematic men: Demographic accounts of male reproductive roles."

104 Michael P. Todaro, "Urbanization, unemployment, and migration in Africa: Theory and policy." 